\title{
Evaluation of hepatoprotective activity of Polygonum equisetiforme methanolic extract
}

\author{
Sayed Abdel Hamid El-Toumy ${ }^{1}$, Josline Yehia Salib ${ }^{1 *}$, Nabila Helmi Shafik ${ }^{1}$, Asmaa Sayed Abd Elkarim¹, Abeer Salama ${ }^{2}$, \\ Enayat Abdel Aziz Omara ${ }^{3}$, Jhehan Micky ${ }^{4}$ \\ ${ }^{1}$ Chemistry of Tannins Department, National Research Center, Cairo, Egypt. \\ ${ }^{2}$ Pharmacology Department, National Research Center, Cairo, Egypt. \\ ${ }^{3}$ Pathology Department, National Research Center, Cairo, Egypt. \\ ${ }^{4}$ Organic Chemistry Department, Faculty of Sciences, Al Azhar University, Cairo, Egypt.
}

\section{ARTICLE INFO \\ Received on: 04/03/2019 \\ Accepted on: 27/08/2019 \\ Available online: 04/11/2019}

\section{Key words:}

Arial parts, hepatoprotective

activity, Polygonum

equisetiforme, rats.

\begin{abstract}
In the current study, the methanolic extract of Polygonum equisetiforme aerial parts was assessed for its protective effect towards carbon tetrachloride $\left(\mathrm{CCl}_{4}\right)$-induced hepatic damage in Sprague-Dawley rats. Polygonum equisetiforme extract's hepatoprotective activity was explored by calculating hepatic marker enzyme levels of the rats: alanine aminotransferase (ALT) and aspartate aminotransferase (AST) together with the oxidative stress mediator levels as nitric oxide (NO), malondialdehyde (MDA), glutathione (GSH), glutathione peroxidase (GPx), and superoxide dismutase (SOD). Results showed that the use of the extract at concentrations of 100 and $200 \mathrm{mg} / \mathrm{kg}$ showed a substantial reduction in ALT and AST serum levels as well as a considerable decrease in oxidative stress mediators NO, MDA and an increase in antioxidant enzyme levels GSH, GPx, and SOD. These biochemical results were reinforced by examining the histopathological features of the liver. Thus, the $P$. equisetiforme aerial parts demonstrated marked protective impact of the liver that likely due to the synergistic action of its flavonoids content.
\end{abstract}

\section{INTRODUCTION}

Though the liver is the body's gateway yet unfortunately; its detoxification systems are recognized in this chemical era with elevated concentrations of toxins that cause hepatic toxicity harm (Jin et al., 2005). $\mathrm{CCl}_{4}$ hepatotoxicity is caused by its reactive metabolite radical $\mathrm{CCl}_{3} *$ that attached covalently to the macromolecules and promote to bring lipid peroxidation that liberates lipid peroxides that destroy the liver tissue.

Herbal medicines have been used all over the world for the prevention and management of hepatic illness. Nowadays, clinical investigations have guaranteed the effectiveness of many plants in developing hepatic disorder therapies, so there is a renewed interest of patients with the degenerative hepatic disease

\footnotetext{
"Corresponding Author

Josline Yehia Salib, Chemistry of Tannins Department, National Research Center, Cairo, Egypt.

E-mail: joslineysalib@gmail.com
}

to use herbal therapy from the start or adjuvant (Del Prete et al., 2012; Srivastava and Srivastava, 2018; Wu, 2016). These herbal remedies depend on either capturing the free radical or inhibiting enzyme in their mode of action (Al-Snafi, 2016). By inhibiting and/or decreasing lipid peroxidation and growing antioxidant enzymes [glutathione (GSH), superoxide dismutase (SOD)...], the preventive impact of plant polyphenolic extracts reduces this damage. These effects will result in depletion in serum liver enzymes activity, hepatocyte growth factor levels, and cause marked improvement in the histological feature of liver fibrosis (El-Toumy et al., 2011; Salib et al., 2014).

Plants of the genus Polygonum comprise approximately 300 species of 1,500 species of the family Polygonaceae and have been commonly used in folk medicine. Modern studies proved that $P$. species possess a variety of pharmacological functions including inflammation suppression (Zhang et al., 2007), bacterial suppression (Cecotti et al., 2012), anti-HIV (Lin et al., 2010), used against kidney stones, antidiabetic, anti-tumor effects (Smolarz et al., 2008), diuretic, and antidiarrheal agents (Baytop, 1999). Polygonum bistorta seeds are used in the Carpathian Basin to cure 
diarrhea (Rab, 2001). The methanol extract of $P$. sachalinensis had antioxidant effects by free radical-scavenging activities (Fan et al., 2010). Polygonum aviculare extracts exhibited anti-obesity effects by decreasing the activity of the white adipose tissue and increasing antioxidant activity (Sung et al., 2013). Additionally, $P$. cuspidatum extracts also suppressed the multiplication of mouth tumor cells by inducing caspase-dependent apoptosis, suggesting the extracts might be as a good ingredient due to its effective remedy of mouth tumor (Shin et al., 2011). Polygonum cognatum has been applied as diuretic agents in Turkish ethnomedicine and for the treatment of urinary tract inflammation (Cakilcioglu and Turkoglu, 2010). Different parts of some Polygonum genus are useful in the treatment of anemia, liver problems, and kidney stones (Ghorbani, 2005). As far as we know, P. genus comprises a mixture of different bioactive compounds, including volatile oil, flavonoids, phenylpropanoids, anthraquinones, and terpenoids (Datta et al., 2000; Dong et al., 2014; Wang et al., 2005). In addition, characteristic compounds such as drimane sesquiterpenoids, norsesquiterpenoids, and sulfated flavonoids were isolated from certain species of Polygonum (Fukuyama et al., 1982; Haraguchi et al., 1996). Although a significant trial and botanic data were gathered regarding the pharmacological effects of Polygonum genus (Nkuété et al., 2015), no exhaustive studies have yet been published on Polygonum equisetiforme. Thus, on our progression of the survey program on the flora of Egyptian plants and compounds with antiproliferative effect; the current research target is to evaluate the hepatoprotective impact of the methanolic extract rich in flavonoids (El-Toumy et al., 2017) of P. equisetiforme aerial parts versus $\mathrm{CCl}_{4}$-induced hepatic illness in male Sprague-Dawley rats.

\section{MATERIALS AND METHODS}

\section{Plant material}

Polygonum equisetiforme aerial parts were gathered from the Mediterranean region, Egypt during April 2013 (flowering date). The samples were separately air-dried in the shed, powdered, and kept in tightly sealed round flasks and stored for biological studies. Identification of the plant was confirmed by the Botany Department, Faculty of Science, Cairo University, Egypt (Boulos, 1999). A voucher (P75) is installed in the National Research Centre's herbarium (Cairo, Egypt).

\section{Chemicals and biochemicals}

$\mathrm{CCl}_{4}$ was purchased from Merck, Germany. Silymarin was acquired from Sigma-Aldrich, St Louis, MO. For serum alanine aminotransferase (ALT), aspartate aminotransferase (AST), GSH, glutathione peroxidase (GPx) nitric oxide (NO), malondialdehyde (MDA), SOD, biodiagnostic kits (Biodiagnostic Co., Dokki, Giza, Egypt) were acquired. Solvents and all other used chemicals were of analytical quality.

\section{Phytochemical investigation}

Aerial parts of $P$. equisetiforme were crushed and extracted by soaking at room temperature with $70 \%$ methanol for five folds. To obtain a dry extract, the collaborated methanol extract was concentrated under reduced pressure and lyophilized. Total dry extract was stored at $-20^{\circ} \mathrm{C}$ in the dark until it was used. A sample (100 g) of the dry extract was fractionated by chromatography on polyamide $6 \mathrm{~S}$ column. The column was eluted with water and with water/methanol step-gradient. The similar fractions were collected together to give six major fractions (IVI). The fractions were subjected to Sephadex column LH-20 CC using different percentage of $\mathrm{EtOH}$ or/and $\mathrm{EtOH}-\mathrm{H}_{2} \mathrm{O}$ as solvent system to afford the purified samples of three new flavonoids named; $3,5,7,2^{\prime}, 5^{\prime}$ pentahydroxyflavone $3-O-\beta$-D-glucopyranoside, $3,5,7,2^{\prime}, 5^{\prime}$ pentahydroxyflavone $\quad 3-O-\beta$-D-glucopyranoside 8 C-sulphated,quercetin 3-O- $\beta$-D-glucuronide 6 "-methyl ester 8 -sulphated as well as quercetin 3-O- $\beta$-D-glucuronide methyl ester, quercetin 3-O- $\beta$-D-glucopyranoside, quercetin $7-O-\beta$-Dglucopyranoside, quercetin, myricetin, $P$-methoxygallic acid methyl ester, and gallic acid (El-Toumy et al., 2017).

\section{Animals}

Forty-two Male Sprague-Dawley rats (100-150 g) were used in this study. They were purchased from the Animal House, National Research Center, Egypt. All animals were kept in a controlled air environment $(57 \% \pm 2 \%$ moisture and 12:12 hours light and dark photo-cycle) and $22^{\circ} \mathrm{C} \pm 2{ }^{\circ} \mathrm{C}$ temperature with access to water and ad libitum diet. All experimental methods followed the ethical rules of the National Research Centre's Medical Ethics Committee in Egypt. The animals were observed daily to guarantee that at any point of the investigations the animals did not tolerate.

\section{Acute toxicity study}

Doses of $P$. equisetiforme extract at 100, 200, and 1,000 $\mathrm{mg} / \mathrm{kg}$ b.wt. were given orally to the rats. All rats were examined for the mortality in the duration of 24-72 hours. At a dose of $1,000 \mathrm{mg} / \mathrm{kg}$ b.wt, only one dead animal was noted after 24 hours. Therefore, only doses of 100 and $200 \mathrm{mg} / \mathrm{kg}$ b.wt were selected to guide this study.

\section{Experimental design}

$\mathrm{CCl}_{4}$-induced hepatotoxicity study was performed as stated by Suja et al. (2004). Forty-two male Sprague-Dawley rats (six rats/each) were distributed into seven groups as listed:

Group I: rats were administrated saline orally $(1 \mathrm{ml} /$ $\mathrm{kg}$ b. wt.) for 21 days as normal control.

Groups II and III: $\quad$ rats were orally administrated $P$. equisetiforme extract at two different doses (100 and 200 $\mathrm{mg} / \mathrm{kg} \mathrm{b}$. wt., respectively), alone for 21 days.

Group IV: $\quad$ rats were orally administrated saline for 15 days followed by a single dose of $\mathrm{CCl}_{4}(1.5$ $\mathrm{mg} / \mathrm{kg}$ b.wt.) twice weekly until day 21 .

Group V: the reference drug silymarin $(25 \mathrm{mg} / \mathrm{kg}$ b.wt.) was administrated orally for 15 days and $\mathrm{CCl}_{4}(1.5 \mathrm{mg} / \mathrm{kg}$ b.wt.) was conducted twice a week until day 21 .

Groups VI and VII: P. equisetiforme extract (100 and $200 \mathrm{mg} / \mathrm{kg}$ b.wt., respectively) was administrated orally for 15 days, followed by $\mathrm{CCl}_{4}(1.5 \mathrm{mg} / \mathrm{kg}$, b.wt.) twice a week until day 21 .

\section{Blood sample preparation}

All animals were sacrificed by mild ether anesthesia. Sera were separated from the collected blood samples; in 
clean and dry test tubes; by leaving to clot for 10 minutes and centrifuging at $1,500 \mathrm{rpm}\left(4^{\circ} \mathrm{C}\right)$. The clear supernatant serum was kept at $-20^{\circ} \mathrm{C}$ for further investigations of liver enzymes levels and hepatic oxidative stress markers assessment. Liver tissue was also separated for histopathological examination.

\section{Biochemical assays}

Serum enzymes (AST and ALT) activities were assessed colorimetrically using a test-reagent kit as maintained by Reitman and Frankel (1957). According to Lawrence and Burk (1976), the glutathione peroxidase activity was determined by the cyanmethemoglobin technique. Suttle's study (1986) reveals the degree of inhibition of pyrogallol auto-oxidation at an alkaline $\mathrm{pH}$, by the activity of SOD in rat liver cytosol. The level of decreased GSH in the liver tissue homogenate was estimated just as Moron et al. (1979) stated. Hepatic nitric oxide was maintained by Miranda et al. (2001) procedure. The MDA level was described by Uchiyama and Mihara (1978) technique.

\section{Histopathological studies}

Liver sections were cut out and washed quickly with normal saline, then handled thoroughly for histopathological observation. First, the materials were placed in $10 \%$ buffered neutral formalin and paraffin, then layers of $5 \mu \mathrm{m}$ thickness were sorted out in alcohol-xylene series and stained with alum hematoxylin and eosin. For histopathology transformation, the liver sections were examined microscopically (Bancroft and Gamble, 2001).

\section{Statistical analysis}

All information in each group was shown as mean \pm SD of six rats. Among several other procedures, we implanted the one-way variance assessment analysis of variance (ANOVA) for statistical analysis, followed by the least significant difference at $p<0.05$.

\section{RESULTS AND DISCUSSION}

The obtained results revealed that when the animals are pretreated with $P$. equisetiforme extract at 100 and $200 \mathrm{mg} / \mathrm{kg}$ for 6 weeks (groups II and III), it gives normal healthy parameters which revealed the potency hepatoprotectivity of $P$. equisetiforme (Table 1), while oral $\mathrm{CCl}_{4}$ administration showed increased ALT and AST serum concentrations of the group (IV) relative to the control group (I). These enzymes increased impacts justified the hepatic cellular damage, leakage, and liver injury. In comparison to the control group, the oxidative stress mediators levels GSH, GPx, and SOD were significantly decreased, while the NO and MDA levels were remarkably increased (Table 2). $\mathrm{CCl}_{4}$-induced hepatotoxicity results from its metabolic byproduct $\mathrm{CCl}_{3} \cdot$ which alkylates cellular proteins and other macromolecules with frequent attacks on polyunsaturated fatty acids in the presence of oxygen to form lipid peroxides leading to hepatic illness (Bishayee et al., 1995). On the other hand, improvements were seen in rats that had been medicated with silymarin $(\mathbf{V})$ and increased significantly by the administration of $P$. equisetiforme extract at both doses (100 and $200 \mathrm{mg} / \mathrm{kg}$ ) (VI and VII) in comparison with the $\mathrm{CCl}_{4}$ treated group (Tables 1 and 2). The elevated value of GPx and GSH level in the rat's liver tissues when treated with two doses of $P$. equisetiforme extract and Silymarin may result from GSH regeneration or synthesis of de novo GSH (Sanmugapriya and Venkataraman, 2006). Enhancement of lipid peroxidation reported acceleration in MDA levels in the liver, resulting in tissue distortion and deterioration of antioxidant defense mechanisms to scavenge accumulated free radicals (Ashok et al., 2001). Many illnesses were associated with alterations in GSH concentrations and decreased oxidation stress resistance. These changes are significantly reversed on treating the induced rats with both doses of $P$. equisetiforme extract and silymarin. Many scientists have indicated that flavonoids suppress lipid peroxidation (Husain et al., 1987). GSH (sulfhydryl compounds), are one of the wellknown antioxidant substance in organisms, which perform a crucial effect against $\mathrm{CCl}_{4}$-induced injury by covalently binding to $\mathrm{CCl}_{4}$. In the oxidative chain formation, this is believed to be the initial reactant arising in lipid peroxidation and cell membrane disorder (Brattin et al., 1985). By comparing with the control group, the liver GSH quantity was significantly improved with the treatment of $P$. equisetiforme extract at both doses. The concentration of GSH, SOD, and the GPX were used to monitor the emphasis of oxidative stress and chemo-preventive capacity (Hatono et al., 1996). Polygonum equisetiforme extract showed a hepatoprotective impact in the current study, which was resisting to $\mathrm{CCl}_{3} \cdot$ cell damage. The antioxidant system associated with SOD, GPx, and GSH has also been improved, which is an evidence of hepatic tissue repair and plasma membrane maintenance from the deficiency induced by $\mathrm{CCl}_{4}$, particularly in the high dose group (VII), all resulting in the rehabilitation of biological standards. However, $P$. equisetiforme's protective, curative, and antioxidant characteristics could be assigned to the presence of bioactive components in the plant extract, especially flavonoids and other polyphenolic compounds (Al-Qarawi et al., 2004; Gupta et al., 2004). The variation in the enzymatic antioxidant action and the efficacy and dynamics of this plant's pure complexes need more research to ensure that their antioxidant features are linked to their role in the protection of the liver.

By studying the histopathology of the liver, the hepatoprotective capability of the $P$. equisetiforme extract was additionally verified. The control animals' liver section (Fig. 1A) exhibited ordinary hepatic cells. The liver section pretreated with $P$. equisetiforme extract $(100 \mathrm{mg} / \mathrm{kg})$ showed normal photomicrograph with ordinary liver tissue and dilation of hepatic

Table 1. Effect of oral administration of $P$. equisetiforme extract (100 and 200 $\mathrm{mg} / \mathrm{kg}$ ) on AST and ALT serum activity in $\mathrm{CCl}_{4}$-induced hepatotoxicity in rats.

\begin{tabular}{lll}
\hline Groups & AST $(\mathbf{U} / \mathrm{ml})$ & ALT $(\mathbf{U} / \mathbf{m l})$ \\
\hline I (Control) & $63.86 \pm 0.68$ & $44.22 \pm 0.95$ \\
II $($ P. equisetiforme $100 \mathrm{mg} / \mathrm{kg})$ & $63.43 \pm 0.58^{\mathrm{b}}$ & $45.02 \pm 0.48^{\mathrm{b}}$ \\
III $($ P. equisetiforme $200 \mathrm{mg} / \mathrm{kg})$ & $64.86 \pm 0.20^{\mathrm{b}}$ & $45.16 \pm 0.87^{\mathrm{b}}$ \\
IV $\left(\mathrm{CCl}_{4}\right)$ & $85.86 \pm 0.36^{\mathrm{a}}$ & $73.72 \pm 0.15^{\mathrm{a}}$ \\
V (Silymarin) & $81.35 \pm 0.16^{\mathrm{ab}}$ & $70.78 \pm 0.40^{\mathrm{ab}}$ \\
VI (P. equisetiforme $\left.100 \mathrm{mg} / \mathrm{kg}+\mathrm{CCl}_{4}\right)$ & $80.88 \pm 0.30^{\mathrm{ab}}$ & $70.73 \pm 0.32^{\mathrm{ab}}$ \\
VII (P. equisetiforme $\left.200 \mathrm{mg} / \mathrm{kg}+\mathrm{CCl}_{4}\right)$ & $85.01 \pm 0.23^{\mathrm{a}}$ & $70.73 \pm 0.46^{\mathrm{ab}}$ \\
\hline
\end{tabular}

Hepatotoxicity was induced by a single dose of $1.5 \mathrm{ml} / \mathrm{kg}\left(1: 1\right.$ of $\mathrm{CCl}_{4}$ in olive oil $)$ orally. Values represent the mean $\pm \mathrm{SE}$ of six animals for each group.

${ }^{\mathrm{a}} p<0.05$ : Statistically significant from the saline control group.

${ }^{\mathrm{b}} p<0.05$ : Statistically significant from $\mathrm{CCl}_{4}$ group by using ANOVA and LSD. 
Table 2. Effect of oral administration of $P$. equisetiforme (100 and $200 \mathrm{mg} / \mathrm{kg}$ ) on NO, MDA, GSH, GPx, and SOD activity in CCl-induced hepatotoxicity in rats.

\begin{tabular}{|c|c|c|c|c|c|c|c|}
\hline & I & II & III & IV & $\mathbf{v}$ & VI & VII \\
\hline $\mathrm{NO}(\mu \mathrm{mol} / \mathrm{g}$ tissue $)$ & $0.023 \pm 0.0004$ & $0.024 \pm 0.0004^{b}$ & $0.025 \pm 0.0001^{b}$ & $0.037 \pm 0.0011^{\mathrm{a}}$ & $0.027 \pm 0.0006^{6 \mathrm{ab}}$ & $0.026 \pm 0.0005^{\mathrm{ab}}$ & $0.03 \pm 0.0006^{\mathrm{ab}}$ \\
\hline MDA (nmol/g tissue) & $2.06 \pm 0.04$ & $2.10 \pm 0.04^{\mathrm{b}}$ & $2.10 \pm 0.02^{b}$ & $3.42 \pm 0.08^{\mathrm{a}}$ & $2.18 \pm 0.04^{b}$ & $2.16 \pm 0.07^{b}$ & $3.42 \pm 0.02^{\mathrm{a}}$ \\
\hline GSH (mg/g tissue) & $4.35 \pm 0.06$ & $4.18 \pm 0.03^{\mathrm{b}}$ & $4.08 \pm 0.02^{\mathrm{b}}$ & $3.11 \pm 0.08^{\mathrm{a}}$ & $3.84 \pm 0.16^{\mathrm{b}}$ & $3.69 \pm 0.28^{\mathrm{ab}}$ & $3.59 \pm 0.15^{\mathrm{a}}$ \\
\hline GPx $(\mu / g$ tissue $)$ & $936.77 \pm 71.55$ & $882.13 \pm 44.98^{\mathrm{b}}$ & $882.13 \pm 56.94^{b}$ & $242.00 \pm 11.84^{\mathrm{a}}$ & $761.13 \pm 19.90^{\mathrm{ab}}$ & $487.9 \pm 11.04^{\mathrm{ab}}$ & $281.03 \pm 27.38^{\mathrm{a}}$ \\
\hline $\operatorname{SOD}(\mu / \mathrm{g}$ tissue $)$ & $133.54 \pm 2.18$ & $132.58 \pm 1.83^{\mathrm{b}}$ & $131.13 \pm 2.01^{\mathrm{b}}$ & $38.95 \pm 0.40^{\mathrm{a}}$ & $95.56 \pm 1.45^{\mathrm{ab}}$ & $48.15 \pm 2.77^{\mathrm{ab}}$ & $41.13 \pm 0.97^{\mathrm{a}}$ \\
\hline
\end{tabular}

Hepatotoxicity was induced by a single dose of $1.5 \mathrm{ml} / \mathrm{kg}\left(1: 1\right.$ of $\mathrm{CCl}_{4}$ in olive oil $)$ orally.

Values represent the mean $\pm \mathrm{SE}$ of six animals for each group.

${ }^{\mathrm{a}} p<0.05$ : Statistically significant from the saline control group.

${ }^{\mathrm{b}} p<0.05$ : Statistically significant from $\mathrm{CCl}_{4}$ group by using ANOVA and LSD.

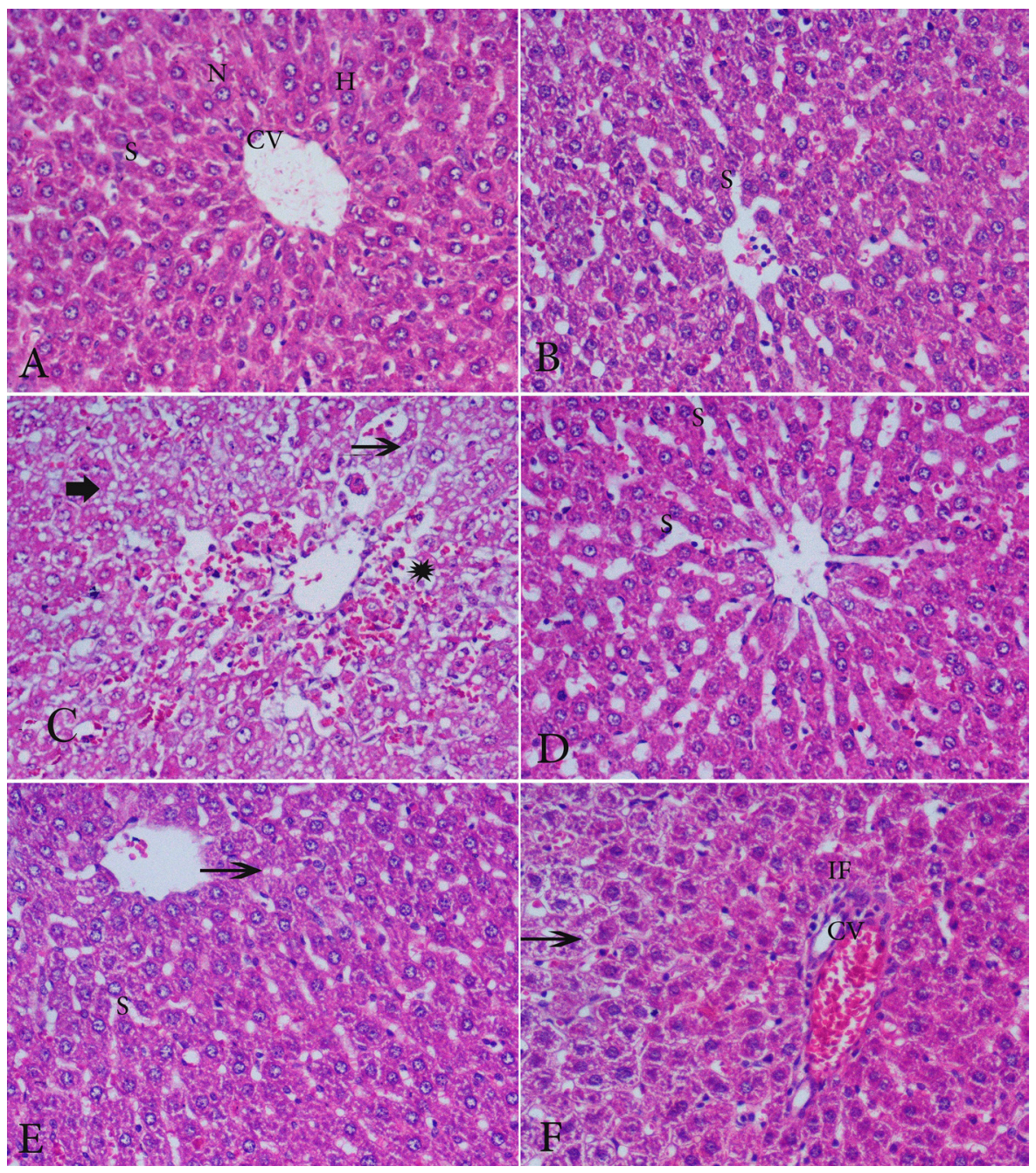

Figure 1. Photomicrographs of hepatic histopathology. (A) Negative control, normal histological picture of the hepatic lobule. (B) Liver section from group III treated with the plant extract at dose $200 \mathrm{mg} / \mathrm{kg}$, No noticeable histological changes, except dilated blood sinusoids. (C) Liver section from $\mathrm{CCl}_{4}$-treated rat showing massive fatty degeneration, cytoplasmic vacuolization, gross necrosis and broad infiltration of lymphocytes and Kupffer's cells around the central vein. (D) Liver section from the group treated with silymarin and $\mathrm{CCl}_{4}$, the histological was similar to that of the control group. (E) Liver section from the group treated with the plant extract at dose $100 \mathrm{mg} / \mathrm{kg}$ and $\mathrm{CCl}_{4}$ showing mild prevention and mild degenerative changes with dilated blood sinusoids. (F) Liver section from the group treated with the plant extract at dose $200 \mathrm{mg} / \mathrm{kg}$ and $\mathrm{CCl}_{4}$ revealed partial amelioration of degenerative changes in hepatocytes, but still showed congested central vein and infiltration of inflammatory cells.

sinusoids (Fig. 1B). Histopathological changes were observed after $\mathrm{CCl}_{4}$ administration (Fig. 1C) indicating liver damage and were in agreement with preceding results that $\mathrm{CCl}_{4}$ causes cell death (Sun et al., 2001), infiltration of mononuclear cell, steatosis and hepatocytes damage, and accelerate the mitotic process in liver (Teocharis et al., 2001). Figures $1 \mathrm{E}$ and $\mathrm{F}$ showed that the liver section of $P$. equisetiforme extract handled in a dose-dependent manner, totally reversed all $\mathrm{CCl}_{4}$-induced deteriorations, with 
mild necrotic hepatocytes and congested central vein Figure 1E at $100 \mathrm{mg} / \mathrm{kg}$ dose only. These observations recommended that treatment with greater extract dose $(200 \mathrm{mg} / \mathrm{kg})$ improved the histoarchitecture and well-formed the arrangements of the hepatic cord (Fig. 1F).

Although the hepatotoxicity caused by $\mathrm{CCl}_{4}$ administration was also reserved by Silymarin treatment (Fig. 1D), yet the morphologic picture of the liver was essentially normalized by the administration of $P$. equisetiforme extract (Group VII) compared to Group IV. However, the liver section in this group (VII) had some diffuse lymphocyte infiltration in the parenchyma along with the normal structure but still the damage of hepatocytes was much less than those treated with Silymarin alone (Fig. 1F and D).

\section{CONCLUSION}

This research demonstrates that $P$. equisetiforme extract (particularly at $200 \mathrm{mg} / \mathrm{kg}$ dose) was capable of hindering hepatic damage induced by $\mathrm{CCl}_{4}$ in rats. Our findings showed that $P$. equisetiforme extract's liver-protective impact is triggered by an increase in the antioxidant-defense system effects and lipid peroxidation suppression.

\section{REFERENCES}

Al-Qarawi AA, Mousa HM, Ali BH, Abdel-Rahman H, ElMougy SA. Protective effect of extracts from dates (Phoenix dactylifera L.) on carbon tetrachloride-induced hepatotoxicity in rats. Intern J Appl Res Vet Med, 2004; 2:176-80.

Al-Snafi AE. Medicinal plants with antioxidant and free radical scavenging effects (part 2): plant based review. J Pharm, 2016; 6:62-82.

Ashok SK, Somayaji SN, Bairy KL. Hepatoprotective effects of Ginkgo biloba against carbon tetrachloride induced hepatic injury in rats. Indian J Pharmacol, 2001; 33:260-6.

Bancroft JD, Gamble M. Theory and practice of histological techniques. 5th edition, Churchill Livingstone, London, New York, Sydney, 2001.

Baytop T. Türkiye' de Bitkilerile Tedavi (Treatment with Plants in Turkey). Istanbul University Publications, Istanbul, Turkey, 1999.

Bishayee A, Sarkar A, Chatterjee M. The hepatoprotective activity of Carrot (Daucuscarota $\mathrm{L}$ ) against carbon tetrachloride intoxication in mouse liver. J Ethnopharmacol, 1995; 47:69-74.

Puplishing

Boulos L. 1999. Flora of Egypt.Vol 1. Cairo, Egypt: Al Hadara

Brattin WJ, Glende EA, Reckangle RO. Pathological mechanisms in carbon tetrachloride hepatotoxicity. Free Radic Biol Med, 1985; 1:27-8.

Cakilcioglu U, Turkoglu I. An ethnobotanical survey of medicinal plants in Sivrice (Elazığ-Turkey). J Ethnopharmacol, 2010; 32:165-75.

Cecotti R, Carpana E, Falchero L, Paoletti R, Tava A. Determination of the volatile fraction of Polygonum bistorta L. at different growing stages and evaluation of its antimicrobial activity against two major honeybee (Apismellifera) Pathogens. Chem Biodivers, 2012; 9:359-69.

Datta BK, Datta SK, Rashid MA, Nash RJ, Sarker SD. A Sesquiterpene acid and flavonoids from Polygonum viscosum. Phytochem, 2000; 54:201-5.

Del Prete A, Scalera A, Iadevaia MD, Miranda A, Zulli C, Gaeta L, Tuccillo C, Federico A, Loguercio, C. Herbal products: benefits, limits, and applications in chronic liver disease. Evid-Based Complement Alternat Med 2012; Article ID:837939.

Dong X, Fu J, Yin X, Li X, Wang B, Cao S, Zhang J, Zhang H, Zhao Y, Ni J. Pharmacological and other bioactivities of the genus Polygonum - a review. Trop J Pharm Res, 2014; 13:1749-59.
El-Toumy SA, Omara EA, Brouard I, Bermejo J. Evaluation of hepatoprotective effect of Artimesia monosperma against Carbon tetrachloride induced hepatic damage rat. Aust J Basic Appl Sci, 2011; 5:157-64.

El-Toumy SA, Salib JY, Shafik NH, El-Karim ASA, Micky JA, Farag AA. New flavonoids from the aerial parts of Polygonum equestiform SM (Polygonaceae). Inter J Pharm Pharm Sci, 2017; 9:166-70.

Fan P, Terrier L, Hay AE, Marston A, Hostettmann K. Antioxidant and enzyme inhibition activities and chemical profiles of Polygonum sachalinensis F. Schmidt ex Maxim (Polygonaceae). Fitoterapia, 2010; 81:124-31.

Fukuyama Y, Sato T, Asakawa Y, Takemoto T.A potent cytotoxic warburganal and related drimane-type sesquiterpenoids from Polygonum hydropiper. Phytochemistry, 1982; 21:2895-8.

Ghorbani A. Studies on pharmaceutical ethnobotany in the region of Turkmen Sahra, north of Iran: (Part 1): general results. J Ethnopharmacol, $2005 ; 102: 58-68$

Gupta M, Mazumder UK, Kumar TS, Gomathi P, Kumar RS Antioxidant and hepatoprotective effects of Bauhinia racemosa against paracetamol and carbon tetrachloride induced liver damage in rats. Iran J Pharmacol Ther, 2004; 3:12-20.

Haraguchi H, Ohmi I, Sakai S, Fukuda A, Toihara Y, Fujimoto T, Okamura N, Yagi A. Effect of Polygonum hydropiper sulfated flavonoids on lens aldose reductase and related enzymes. J Nat Prod, 1996; 59:443-5.

Hatono S, Jmenez A, Wargovion MJ. Chemopreventive effect of $S$-allylcysteine and relation to the detoxification enzyme glutathione $S$-transferase. Carcinogenesis, 1996; 17:1041-4.

Husain SR, Cillard J, Cillard P. Hydroxyl radical scavenging activity of flavonoids. Phytochemistry, 1987; 26:2489-91.

Jin YS, Sa JH, Shim TH, Rhee HI, Wang MH. Hepatoprotective and antioxidant effects of Morus bombycis Koidzumi on $\mathrm{CCl}_{4}$-induced liver damage. Biochem Bioph Res Co, 2005; 329:991-5.

Lawrence RA, Burk RF. Glutathione peroxidase activity in selenium-deficient rat liver. Biochem Biophys Res Commun, 1976; 71 952-8.

Lin HW, Sun MX, Wang YH. Anti-HIV activities of the compounds isolated from Polygonum cuspidatum and Polygonum multiflorum. Planta Med, 2010; 70:889-92.

Miranda KM, Espey MG, Wink DA. A rapid simple spectrophotometric method for simultaneous detection of nitrate and nitrite. Nitric Oxide, 2001; 5:62-71.

Moron MS, Depierre JW, Mannervik B. Levels of glutathione, glutathione reductase and glutathione $\mathrm{S}$-transferase activities in rat lung and liver. Biochim Biophys Acta, 1979; 582:67-78.

Nkuété AHL, Migliolo L, Wabo HK, Tane P, Franco OL. Evaluation of multiple functions of Polygonum genus compounds. Eur J Med Plants, 2015; 6(1):1-16.

Rab J. 2001. Népinövényismeret a Gyergyói-medencében. Pallas Akadémia Könyvkiadó, Csíkszereda, 236.

Reitman S, Frankel A. Colorimetric method for determination of serum glutamate oxaloaectate and glutamic pyruvate transaminase. Am J Clin Pathol, 1957; 28:56-8.

Salib JY, Kassem MES, Raslan MM. Antioxidant, anticancer activities and a novel alkaloid of the aerial parts of Ricinus communis. J Pharm Res, 2014; 8(12):1764-7.

Sanmugapriya E, Venkataraman S. Studies on hepatoprotective and antioxidant actions of Strychnos potatorum Linn. seeds on $\mathrm{CCl}_{4}$ induced acute hepatic injury in experimental rats. J Ethnopharmacol, 2006; 105:154-60.

Shin JA, Shim JH, Jeon JG, Choi KH, Choi ES, Cho NP, Cho SD. Apoptotic effect of Polygonum cuspidatum in oral cancer cells through the regulation of specificity protein 1 . Oral Dis, 2011; 17:162-70.

Smolarz HD, Budzianowski J, Bogucka-Kocka A, Kocki J, Mendyk E. Flavonoid glucuronides with anti-leukaemic activity from Polygonum amphibium L. Phytochem Anal, 2008; 19:506-13. 
Srivastava R, Srivastava P. Hepatotoxicity and the role of some herbal hepatoprotective plants in present scenario. G J Dig Dis, 2018; 3:2-5.

Suja SR, Latha PG, Pushpangadan P, Rajasekharan S. Evaluation of hepatoprotective effects of Helminthostachys zeylanica (L) Hook against carbon tetrachloride-induced liver damage in Wistar rats. J Ethanopharmacol, 2004; 92:61-6.

Sun F, Hamagawa E, Tsutsui C, Ono Y, Ogiri Y, Kojo S. Evaluation of oxidative stress during apoptosis and necrosis caused by carbon tetrachloride in rat liver. Biochem Biophys Acta, 2001; 1535: $186-91$.

Sung YY, Yoon T, Yang WK, Kim SJ, Kim DS, Kim HK. The Antiobesity effect of Polygonum aviculare L. ethanol extract in high-fat. Evid-based Compl Alt, 2013; 2013:626397.

Suttle NF. Copper deficiency in ruminants, recent developments. Vet Record, 1986; 119:519-22.

Teocharis SE, Margeli AP, Skaltsas SD, Spiliopoulou CA, Koutselinis AS. Induction of metallothionein in the liver of carbon tetrachloride intoxicated rats: an immuno-histochemical study. Toxicol, 2001; 161:129-38.

Uchiyama M, Mihara M. Determinationof malonaldehyde precursor in tissues by thiobarbituric acid test. Anal Biochem, 1978; $86: 271-8$.
Wang KJ, Zhang YJ, Yang CR. Antioxidant phenolic compounds from rhizomes of Polygonum paleaceum. J Ethnopharmacol, 2005; 96: 483-7.

Wu YH. Naturally derived anti-hepatitis B virus agents and their mechanism of action. World J Gastroenterol, 2016; 22:188-204.

Zhang YZ, Shen JF, Xu JY, Xiao JH, Wang JL. Inhibitory effects of 2,3,5,4'-tetrahydroxystilbene-2-O- $\beta$-D-glucoside on experimental inflammation and cyclo-oxygenase 2 activity. J Asian Nat Prod Res, 2007; 9:355-63.

How to cite this article:

El-Toumy SAH, Salib JY, Shafik NH, Elkarim ASA, Salama A, Omara EAA, Micky J. Evaluation of hepatoprotective activity of Polygonum equisetiforme methanolic extract. J Appl Pharm Sci, 2019; 9(11):054-059. 